\title{
PEDIATRINĖ MELANOMA: ATVEJO APRAŠYMAS
}

\author{
Rugilè Pikturniené $\dot{1}^{1}$ Jolanta Česiené ${ }^{1}$, Kristijonas Česas ${ }^{2}$ \\ ${ }^{1}$ Klaipédos universitetine ligonine, ${ }^{2}$ Vilniaus universiteto Medicinos fakultetas
}

Raktažodžiai: melanoma, pediatrija, diagnostika, reti navikai.

\begin{abstract}
Santrauka
Pediatrinè melanoma - tai melanoma, išsivysčiusi iki 20 metų amžiaus. Tai yra retas susirgimas, sudarantis $1-4 \%$ visų melanomos diagnozių [1,2]. Diagnozès nustatymas neretai sudètingas, ypač vaikams prieš lytinę brandą. Tuo metu melanomos klinikinè raiška yra nespecifinè: nepigmentuotas ar nepiktybiškai atrodantis darinys, kuris dèl pavèluotos ar neteisingos diagnozès nèra pradedamas gydyti laiku ar teisingai [3]. Pristatomas klinikinis atvejis: 10 metų berniukui diagnozuota melanoma. Navikas buvo pašalintas chirurginiu būdu. Šiuo metu pacientas stebimas dèl galimo ligos progresavimo.
\end{abstract}

\section{Ivadas}

Melanoma vaikysteje ir paauglysteje - retai pasitaikanti diagnozè. Melanoma sudaro $1-3 \%$ navikų, diagnozuojamu jaunesniems nei 20 metų pacientams, ir tik 0,9\% vaikams iki 15 metų [4,5]. Nors pediatrinè melanoma pasitaiko retai, jos dažnis kasmet didèja.

Histologiškai pediatrinė melanoma, taip pat kaip ir suaugusiujų, klasifikuojama į tipus. Dažniausiai pasitaikantys pediatrinès melanomos tipai, aprašomi literatūroje, yra paviršiumi plintanti ir nodulinè melanoma. Retesni melanomos tipai: akralinè melanoma, lentigo maligna melanoma, desmoplastinè, smulkių ląstelių melanoma, melanoma su Spitzoid požymiais yra aprašomi, tačiau kur kas rečiau. Lentigo maligna ir desmoplastine melanoma yra labai retos formos, nes išsivysto tose kūno vietose, kurios yra ilgą laiką veikiamos saulès šviesos. Dažniausiai pasitaiko vyresnio amžiaus žmonèms [6].

Svarbiausi ligos eigos prognostiniai faktoriai yra melanomos storis, išopèjimas, stadija diagnozės nustatymo metu (sritinių limfmazgių įtraukimas ir tolimosios metastazès) [7].

Klinikiniai tyrimai parodè, kad penkių metų išgyvenamumas diagnozavus in situ ligą siekia 100\%, esant lokali- zuotai ligai - $93-96 \%$, regioninei metastatinei ligai - 68 $-77 \%$, esant tolimosioms metastazèms $-11-57 \%$ [1]. Rizikos faktoriai pediatrinei melanomai yra tokie pat, kaip ir suaugusiujų, tai : šviesi oda, šviesūs plaukai ,arba raudonplaukiai, strazdanos, sunkiai atsirandantis įdegis arba dažni nudegimai sauleje. Taip pat ilgas laikas, praleistas sauleje, daugybiniai melanocitiniai apgamai, displazinių apgamų sindromas, šeimineje anamnezeje buvusi melanoma. Pediatriniams pacientams riziką susirgti melanoma didina pigmentinè kseroderma, dideli ịgimti melanocitiniai apgamai ir imunosupresija $[4,6,8]$.

Pediatrinè melanoma, ypač prieš lytinę brandą, tampa diagnostiniu iššūkiu. Diagnozuojant neretai klasikiniai simptomai nèra stebimi, ypač pirmaisiais gyvenimo metais[8,9].

Darbo tikslas: pateikti 10 metų berniuko melanomos klinikinị atvejị.

\section{Atvejo aprašymas}

10 metų berniuką šeimos gydytoja atsiuntė dermatologo apžiūrai, pastebèjusi pakitusị apgamą blauzdos apatiniame trečdalyje. Atliekant siaskopinį ištyrimą stebètas atipinis melanocitinis apgamas. Darinys buvo chirurgiškai pašalintas. Atlikus histologini ištyrimą gauta išvada: invazinè melanoma, pT1a, II lygis pagal Klarką (Clark) . Naviko storis iki $0,5 \mathrm{~mm}$ (1 pav). BRAF geno mutacijų nerasta. Atlikus periferinių limfmazgių echoskopiją patologinių limfmazgių nebuvo stebèta. Multidisciplininio konsiliumo metu buvo nutarta atlikti platesnę naviko vietos eksciziją. Histologiniame tyrime navikinès infiltracijos nebuvo stebėta. Pacientas nukreiptas tolimesniam dermatologo, onkologo aktyviam stebejimui. Atliekami žymenų S100, LDH tyrimai, limfmazgių, pilvo organų echoskopijos, plaučių rentgenogramos. Pakitimų nèra stebèta.

\section{Diskusija}

Lyginant vaikų ir suaugusiujų melanomą, klinikiniuose tyrimuose aprašoma, kad pavèluota pediatrinès melanomos diagnozė pasitaiko gana dažnai. Jaunesniems pacientams pirminès diagnozès metu stebima labiau pažengusi liga nei 


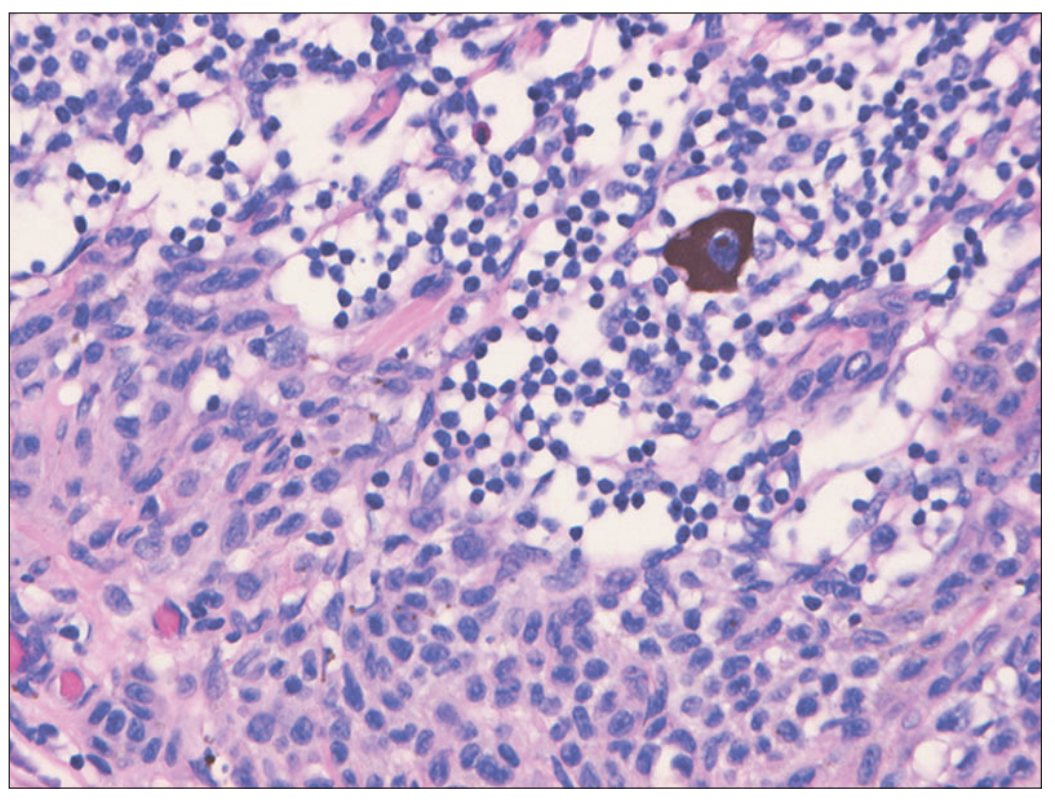

1 pav. Skaitmeninė darinio mikroskopija. Dažyta hematoksilinu ir eozinu. Stebimas didelis mitozinis aktyvumas, atipiniai melanocitai. Padidinta 20 kartų. atvejis parodo, kad vaikui naujai atsiradęs, netipinis, kraujuojantis, keliantis įtarimus darinys galètų būti melanoma. Mūsų pristatytas pacientas neturejo jokių rizikos atvejų: buvo 10 metų amžiaus - šiuo amžiaus laikotarpiu melanomos išsivystymas yra labai retas, gyveno šalyje, kur saulès spinduliuote yra žalinga tik vasaros metu, buvo saugomas nuo žalingų saulès spindulių naudojant kremus su spf apsauga. Atvejis patvirtina, kad pacientui, kuris net neturi rizikos veiksnių, svarbu ịvertinti galimą piktybinį naviką melanomą.

\section{Literatūra}

1. Austin MT, Xing Y, Hayes-Jordan AA. et al. Melanoma incidence rises for children and adolescents: an epidemiologic review of pediatric melanoma in the United States. J Pediatr Surg 2013; 48:2207.

https://doi.org/10.1016/j.jpedsurg. 2013.06.002

2. Strouse JJ, Fears TR, Tucker MA, Wayne AS. Pediatric melanoma: risk factor and survival analysis of the surveillance, epidemiology and end results database. J Clin Oncol 2005; 23:4735.

https://doi.org/10.1200/JCO.2005.02.899

3. Averbook BJ, Lee SJ, Delman KA. et al. Pediatric melanoma: analysis of an international registry. Cancer 2013; 119:4012. https://doi.org/10.1002/cncr.28289

4. Jen M, Murphy M, Grant-Kels JM. Childhood melanoma. Clin Dermatol 2009 November; 27 (6): 529-36.

https://doi.org/10.1016/j.clindermatol.2008.09.011

5. Pappo AS. Melanoma in children and adolescents. Eur J Cancer 2003 December; 39 (18): 2651-61.

https://doi.org/10.1016/j.ejca.2003.06.001

6. Brenn T, McKee PH. Melanoma in children and adolescents. Diagnostic Histopathology 2008 January 21; 14 (1). https://doi.org/10.1016/j.mpdhp.2007.11.004

7. Cordoro KM, Gupta D, Frieden IJ, McCalmont T, Kashani -Sabet M. Pediatric melanoma: results of a large cohort study and proposal for modified $\mathrm{ABCD}$ detection criteria for children. J Am Acad Dermatol 2013 June; 68 (6): 913 -25.

https://doi.org/10.1016/j.jaad.2012.12.953

8. Wong JR, Harris JK, Rodriguez-Galindo C, Johnson KJ. Incidence of childhood and adolescent melanoma in the United States: 1973- 2009. Pediatrics 2013 May; 131 (5): 846-54. https://doi.org/10.1542/peds.2012-2520

\section{Išvada}

Pristatytame klinikiniame atvejyje darinys neatitiko 3 iš 4 kriterijų, tai buvo tik naujai atsiradęs darinys. Šis klinikinis
9. Moscarella E, Piccolo V, Argenziano G, Lallas A, Longo C, Castagnetti F, Pizzigoni S, Zalaudek I. Problematic lesions in 


\section{4}

children. Dermatol Clin 2013 October; 31 (4): 535-47, vii. https://doi.org/10.1016/j.det.2013.06.003

10. Abbasi NR, Shaw HM, Rigel DS, Friedman RJ, McCarthy WH, Osman I, Kopf AW, Polsky D. Early diagnosis of cutaneous melanoma: revisiting the ABCD criteria. JAMA 2004 December 8; 292 (22): 2771-6.

https://doi.org/10.1001/jama.292.22.2771

\section{Pediatric melanoma: case report}

\section{R.Pikturnienė, J.Česienė, K.Česas}

Key words: pediatric, melanoma, diagnosis, rare tumors. Summary

Pediatric melanoma is a cancer reported in patients under 20 years of age. Melanoma is a rare diagnosis in the pediatric population accounting for $1-4 \%$ of all melanoma diagnosis. Diagnosis is not rarely complicated, especially before puberty. Due to its rarity and diagnostic challenges, pediatric patients may be expected to present with poorer prognostic features [3]. Melanoma may be atypical. For this reason diagnosis is often late or wrong. We present a 10-year-old boy who developed malignant melanoma. Melanoma was surgically removed. Patient is followed up due to disease progression.

Correspondence to: rugile.cesaite@gmail.com

Gauta 2018-12-07 